\title{
NOTES ON COOPER'S HAWK NESTING IN WINNIPEG
}

JEAN BANCROFT, 306-200 Tuxedo Boulevard, Winnipeg, Manitoba. R3P OR3

The Cooper's Hawk, often known as the "chicken hawk," has been described as a "feathered ferocity" and "one of hawkdom's more bloodthirsty villains." An accipiter preying mainly on birds, it sometimes attacks birds at feeders, and also preys on small mammals and reptiles. ${ }^{6}$ Due to its bad reputation, "it has been regarded for generations as a pest to be eliminated," especially by poultry farmers. ${ }^{1,5}$

This species used to be quite common before World War II throughout its range, viz. all of the United States, Mexico and southern Canada, but it has declined considerably and, in some parts, is regarded as an endangered species. ${ }^{5}$ There are three reasons given for its decline: killing by farmers, contact with pesticides, and loss of woodland areas for nest sites. In Illinois, for example, steps are being taken to encourage the preservation of this species. ${ }^{5}$

Cooper's Hawks have been known to nest in Winnipeg and outlying areas, but few details have been reported, according to Rudolph Koes (pers. comm., 1992). I would like to offer my brief notes in order to encourage more people to take an interest in these birds.

From early spring to late fall, I make frequent morning visits to a wooded park not far from where I live, walking for exercise and enjoyment. I am now 81, and live alone, so I cherish visits to Assiniboine Park here in Winnipeg. The Assiniboine River runs along the park; a nearby pedestrian bridge offers shelter for hundreds of nesting Cliff Swallows. The park is a wonderful place to watch birds, particularly during migration when warblers pass through in abundance.

On 11 May 1990 I discovered a Cooper's Hawk nesting about $18 \mathrm{~m}$ from the ground in a Black Ash, just east of the locelly famous "English Garden." On 27 June, on a visit to observe the nesting Cliff Swallows, I heard many swallow alarm calls. Hurrying to an open space a few hundred metres from the hawk's nest, I was fascinated to see the pair of Cooper's Hawks circling wildly amongst hundreds of swallows. The hawks were on a hunting flight, but I was unable to remain for any length of time to view the results.

I last saw a Cooper's Hawk in this area on 5 Septımber when an adult pursued a group of American Crows. There were three young produced at this nest, according to George Holland (pers. comm., 1990). He noticed that the male caught a Red Squirrel 
and an American Robin.

On 7 April 1991 I was delighted to see a Cooper's Hawk fly to a giant Black Ash and deposit some sticks in the crotch of three large upright branches, about $15 \mathrm{~m}$ from the ground. This was not far from the 1990 nest site. Bent notes that it is common for this species to "return to the same patch of woods to nest for several years in succession."

The male chooses the nest site, and usually he builds a new nest each year, sometimes choosing an old crow or squirrel nest as a base. .,6 $^{3}$ While the male labours carrying the twigs, the female (the larger of the two) perches nearby. Much of her food is provided by the male. ${ }^{6}$ Bent claims that both sexes build; Uvardy states that the male builds with the "female's assistance."1.7

By 24 April the nest was completed. Four days later, with a wind of $70 \mathrm{~km} / \mathrm{hour}$ and rain, the female was sitting low in the nest. Cooper's Hawks generally have three to five bluish-green eggs, incubated by both sexes, but mostly by the female. ${ }^{1,2}$ On 8 May, the male flew to the nest where the female sat and then he darted quickly downwards into a nearby thicket. I could not see if any food was delivered to the female. Both birds then flew from the nest site, probably to hunt. 6

On 7 May the male perched on a high branch about $30 \mathrm{~m}$ from the nest site between $1100 \mathrm{~h}$ and 1130 $h$. During this period the male twice flew to the nest. I believe he must have delivered food to the female because she moved around a great deal and appeared to be tearing at something. Many leafy branches obscured the nest.
On 13 May I heard loud, rapid kekkek-kek-kek calls, as described by Uvardy and watched the male fly over the nearby duck pond. ${ }^{7}$ He disappeared into another wooded area not too far away, but out of my view.

On 14 June at $1015 \mathrm{~h}$, when the female flew off the nest, I noticed two young moving about in the nest. The incubation period is said to be 36 days. $^{2,6}$ After the eggs hatch, the male reportedly is banished from the nest. Hohn writes: "Brown and Amadon state that the female carries the egg shells 50 yards or farther from the nest." 4 The female broods her chicks until they are two weeks old. ${ }^{6}$ During this time, the male "may not bring food to her nor feed the nestlings. Instead, the food is delivered to a spot near the nest, where the female takes it from him." 6

On 18 June I noticed a nestling sitting up in the nest and heard the male call. Ten days later, two fledged young were perched on a branch above the nest. On 5 July two fledged young perched sideways on a branch near the nest and flapped their wings. The thick foliage made it difficult to get a good view. Finally I noticed that there were three young perched on branches near the nest, and about $12 \mathrm{~m}$ from the ground. On 20 July loud shrill calls came from another part of the wooded area about $30 \mathrm{~m}$ away. The nest was now deserted.

On 29 July I observed one young hawk fly underneath the bridge. I hurried down the embankment and managed to focus my binoculars on a ledge above numerous Cliff Swallow nests. The hawk made no attempt to catch any swallows, though there were many young swallows out of the nests. 
By 3 August I had visited the nest site at least 26 times. That morning I heard an adult Cooper's Hawk call loudly about $30 \mathrm{~m}$ from the nest site. I noticed one fledgling perched upright on a branch high above the spot where this adult zoomed into the woods. Bent notes that this species "surprises its prey by a sudden, swift dash, pouncing upon it before it has a chance to escape." The last time I saw a Cooper's Hawk in the park in 1991 was 26 August.

\section{Acknowledgement}

I am grateful to Robert Nero for constructive criticism of two drafts of this article.

1. BENT, A.C. 1937. Life histories of North American birds of prey. US
Natl. Mus. Bull. 167, Part 1, 409 pp.

2. GODFREY, W.E. 1986. The birds of Canada. Natl. Mus. Nat. Sci., Ottawa. $595 \mathrm{pp}$.

3. HARRISON. H.H. 1975. A field guide to birds' nests in the United States east of the Mississippi River. Houghton Mifflin, Boston. 257 pp.

4. HOHN, E.O. 1983. Female Cooper's Hawk breeding in brown plumage, apparently for four years. Blue Jay 41:209.

5. ILLINOIS DEPARTMENT OF CONSERVATION. 1991. "Outdoor Highlights," Cooper's Hawk. Nature Society News, July 1991. p. 15.

6. NERO, R.W. 1981. Fast-flying forest hawks. Defenders 56:28-32.

7. UDVARDY, M.D.F. 1977. The Audubon Society field guide to North American birds, western region. A.A. Knopf, New York. 855 pp.

In 1855 a famous Squamish American Indian Chief, Seatl, after whom Seattle, Washington is named, said words that to-day are even more appropriate: "What is man without the beasts? If all the beasts were gone, man would die from great loneliness of spirit, for whatever happens to the beasts also happens to man. All things are connected." John Carroll, 1991. "Birds, Beasts and Flowers." 